\title{
ANNEXATION IMPACT ON MUNICIPAL EFFICIENCY
}

\author{
Gaines H. Liner
}

\begin{abstract}
In recent decades, annexation has been the major form of city growth in all parts of the United States except the Northeast. Several studies in the literature suggest that high annexation activity leads to bureau inefficiency. Using 1960s data in a national sample of 403 cities, this study found annexation activity to be inversely correlated with the growth rates of two major indicators of municipal bureau inefficiency. The annexation of people was found to be inversely correlated with rates of growth of per capita municipal employment and per capita fire and police expenditures. Total expenditures per capita were not found to be statistically related to changes in annexation activity. These results indicate that annexation activity per se does not lead to bureau inefficiency in cities.
\end{abstract}

\section{INTRODUCTION}

Annexation has played a central role in city growth throughout much of the twentieth century. The historical significance of annexation activity has been addressed by Bollens (1949), Bromley and Smith (1973), Kaufman (1975), Klaff and Fuguitt (1978), and others. Dye (1964), Wheeler (1965), MacManus and Thomas (1979), Dusenbury (1980), Galloway and Landis (1986), and Liner (1990) have attempted to evaluate the impact of different annexation laws on annexation activity. Other approaches have identified determinants of municipal expenditure (Liebert 1974; Sly and Tayman 1980; Hufbauer and Sevem 1975; Bahl and Saunders 1965; Gabler 1971). Others have found annexation to be a determinant of municipal and local government expenditures (Brown 1967, 1968; Cho 1969; Mehay 1981). Attempts to relate institutional constraints to the competitive nature of municipal service delivery include Martin and Wagner (1978), Wagner and Weber (1975), and Mehay (1981). Empirical studies by Martin and Wagner and by Mehay addressed the probable impact of one specific structural change on bureau growth and efficiency, the enactment of the Knox-Nisbet Act of 1963 in California, which created local agency formation commissions (LAFCO) in all but one of the state's 58 counties. ${ }^{1}$ Each LAFCO, composed of representatives from local government jurisdictions, was given the authority to permit or reject any proposed boundary change, including incorporation, annexation, consolidation, and dissolution. Effectively, existing local governments were given control over entry into the field of municipal service delivery. Both Martin and Wagner and Mehay argued that LAFCOs used their authority to significantly reduce new

\footnotetext{
*Associate Professor of Economics, The University of North Carolina at Charlotte.
} 
incorporations in California. More importantly, they concluded that the effect would be a more rapid growth in government spending due to the newfound monopoly power. This monopoly power was thought to be exercised through reduced incorporation and enhanced annexations by existing cities.

The Martin and Wagner study considered the impact of enactment of the Knox-Nisbet Act on changes in total current expenditures of all governmental units in Califormia counties. In a related vein, Mehay was one of the first to estimate the direct impact of annexation on the levels of expenditures by municipalities in a multicity study. He estimated the impact of different rates of annexation of people in 157 cities on the percent change in municipal spending (total, public safety, public works, and general government). He concluded that cities that grew through high annexation rates had higher expenditure growth rates than did cities that experienced low annexation rates. Furthermore, he concluded that an institutional shift toward annexation increased the service monopoly of existing municipalities .

Although Mehay addressed the impact of annexation directly, he failed to properly account for the fact that municipal expenditures would rise with annexation, regardless of the rate of annexation, because more people and area must be served after annexation than before annexation. Specifically, the study failed to address the question of what happens to expenditure per capita or to municipal employment per capita when annexation takes place at different rates. To have proposed that expenditures grew faster with higher annexation rates is not very interesting; however, to conclude that expenditures per resident served went up at higher rates with higher annexation rates would have been much more persuasive in arguing for the bureau inefficiency-enhancing aspect of rapid annexation. An even better accounting of municipal efficiency would have been a measure of how municipal employment changed as annexation occurred. Employment is a big percentage of municipal expenditures and is directly correlated to bureau growth and costs of operation.

The present study extends Mehay's inquiry in three ways. First, expenditures, as indicators of efficiency, are expressed in terms of the number of residents served. Second, efficiency is measured in terms of the number of people employed in municipalities. Finally, the sample of cities is expanded from only California, as in the Mehay study, to include cities in all regions of the United States except the Northeast. A total of 403 cities in 41 states are included.

Mehay argued that annexation permits existing cities to enhance their monopoly position in municipal service delivery, which reinforces existing barriers to incorporation. He further concluded that annexation allows a city to increase in size relative to the total metropolitan area, resulting in greater centralization in local public service delivery. These are not issues to debate. 
However, the assertion is at issue that increased annexation results in faster growth in municipal expenditures, and that this growth in municipal expenditures is evidence of more bureau inefficiency. If spending per person served went up at a higher rate with annexation, then the negatives of the monopoly position of the city would have been enhanced. However, if the spending per person served did not go up or actually went down with annexation, then the alleged bureau inefficiency argument associated with annexation could not be supported. If the rate of annexation were found to be negatively correlated with growth in per capita spending, then one of the following might have been argued: annexation increased municipal efficiency, which reduced costs per person; or annexation caused the available revenues to be spread over more people and a greater area, and thus diluted the quality of service rendered. If expenditures per capita had gone down, increased bureau inefficiency might yet have gone up. Bureau inefficiency could have increased, and the effect could have been offset by increased efficiencies elsewhere or by expenditures spread over more people. Thus, the inefficiency could have been masked. One way to unmask such an inefficiency would be to measure how the number of municipal employees changed with annexation. If the growth in the number of employees were greater than the growth in population due to annexation, then one could have more persuasively argued that high annexation activity led to bureau inefficiency. However, if growth in employees per capita were negative or less than the growth in population due to annexation, then Mehay's argument would be substantially damaged or refuted. These questions will be addressed further in a later section of the paper. The Mehay hypothesis of increased expenditure growth rates from higher annexation rates will be tested first by using his form of dependent variable to corroborate his results, and then the alternative expenditures per capita form of dependent variable will be used. Second, employment per capita will be substituted for expenditures per capita.

To implement the study, a sample of 403 cities containing at least 25,000 people (1960) that annexed during the $1960-1970$ decade is used. ${ }^{2}$ The 1960 1970 decade might seem dated, but there are two important reasons for using data from that period. First, to corroborate Mehay's results, the 1960s data are essential. He used one state's data from the 1960s. Second, the predominant force driving annexations in a city during the 1960s-attempts to preserve the revenue base-is the predominant force driving annexations today. Consequently, the use of data from the 1960s does not take away from the analysis. States that allowed annexation only under legislatively determined annexation laws were not included in the sample. ${ }^{3}$ The annexation activity in these states was so low that their impact was inconsequential. Thus, their omission should not negatively impact the findings of this study. ${ }^{4}$ 


\section{THE MODEL}

The model forms employed in this section are a variation of the model used by Mehay. First, municipal expenditures are expressed as a function of annexation and controls previously found important in the literature. From this approach, a comparison can be made with Mehay's results. Second, the basic model is changed to measure expenditures on a per capita basis, thus tying expenditures to a common denominator, i.e., the number of people served both before and after annexation. Third, to get an alternative indication of the resources committed to running municipal governments, municipal employment will be substituted for expenditures. The first relationship is estimated using the following model form:

$$
\begin{aligned}
& E_{i k}=a_{0}+a_{1} P A N X_{i}+a_{2} I R_{i}+a_{3} M C_{i}+a_{4} P N W_{i}+a_{5} D_{i}+a_{6} M F Y_{i} \\
& a_{7} \mathrm{SUNB}_{\mathrm{i}}+\mathrm{e}_{\mathrm{i}} \\
& \text { where: } \\
& \mathrm{E}_{\mathrm{ik}}=\text { dependent variable: } \\
& \text { percentage change in municipal spending, } 1960-1970 \text {, in } \\
& \text { spending category } \mathbf{k} \text { for city } \mathbf{i} \text {. } \\
& \mathrm{PANX}_{\mathrm{i}}=\text { ratio of population annexed, } 1960-1970 \text {, to } 1960 \\
& \text { population. } \\
& \mathrm{IR}_{\mathbf{i}} \text { = percentage change in intergovernmental aid, } \\
& \text { 1960-1970. } \\
& \mathrm{MC}_{\mathrm{i}} \text { = dummy variable, } 1 \text { for cities in standard metropolitan } \\
& \text { statistical areas in 1960, } 0 \text { otherwise. } \\
& \mathrm{PNW}_{\mathrm{i}}=\text { percentage change in nonwhite population, } 1960-1970 . \\
& \mathrm{D}_{\mathrm{i}} \quad=\text { percentage change in population density, } 1960 \text { city area, } \\
& \text { 1960-1970. } \\
& \text { MFY }_{\mathbf{i}}=\text { percentage change in median family income, } 1960-1970 . \\
& \text { SUNB }_{i}=\text { dummy variable }=0 \text { for Sun Belt cities, } 1 \text { for others. } \\
& \mathrm{e}_{\mathrm{i}} \quad=\text { stochastic disturbance term. }
\end{aligned}
$$

The IR variable is expected to have a positive sign, since many local government functions are supported through funds made available from state and federal governments. During the 1960s, intergovernmental aid became a significant element in city budgets. Furthermore, city governments did not share equally in intergovernmental aid (Fossett 1983; Gustely 1979). Much of the aid to cities in the 1960s was based on which cities worked most aggressively at getting aid money. Block grants based on funding formulas did not become a significant leveling agent until the 1970s. The PNW variable is expected to have a positive sign for those expenditure categories involving substantial social services, since a higher 
proportion of minorities have historically had lower incomes than whites. The change in population density, D, of the original city area (1960) is included to account for the net effect of births, deaths, in-migration, and out-migration from the original city and is expected to have a coefficient of uncertain sign. This variable differs from the density variable used in the Mehay study because he apparently measured the change in density of the city from the original to the final size. If so, his density variable did not account for the net impact of deaths, births, in-migration, and out-migration separately from the effects of annexation on density. The last control common to the Mehay study is median family income (MFY). The higher the median family income, the higher the expected level of services, except, perhaps, for police and fire, and thus the higher the level of expenditures.

Mehay's tax share variable, $S_{i}$ (measured as percentage change in the ratio of median house value to total assessed property value, 1960-1970, in cityi), was omitted in this study for three reasons. First, tax share accounts for some of the same influences as median family income, and median family income is in the model. Second, his $\mathrm{S}_{\mathrm{i}}$ variable is not a good approximation to tax share. A better measurement of tax share would have been expressed as taxes paid on the median value house relative to the total property tax revenue collected. Mehay's tax share variable appears to have omitted the different tax assessment rates in effect in different cities. Third, although tax share is appropriate conceptually, it suffers from problems of practical application that are not shared by median family income. For example, property taxes collected represent only a portion of all city taxes paid by the median income resident and by others. Furthermore, property tax revenues collected are not uniformly distributed among residential, commercial, and industrial interests in different cities. Also, in cities of different size, property tax burdens do not necessarily fall equally on median income families. ${ }^{5}$ For these reasons, tax share was omitted and median family income was included in the model.

Also included in this study are two additional controls not used by Mehay. The categorical variable, MC, was included to indicate whether or not a city was in a standard metropolitan statistical area (SMSA). This variable was included to capture the different impacts of urban area size on costs and employment. ${ }^{6}$ The other control, a categorical variable, SUNB, was included to account for the impact of post-automobile cities often found in the Sun Belt. Many of these cities have also been referred to as spread-cities, reflecting relatively nonrestrictive annexation laws. A large number of these cities have experienced much of their growth since the automobile made suburbs an important element of urban life.

The annexation variable, PANX, is the change in city population due to annexation divided by the 1960 city population. Mehay called annexation a proxy 
for bureau growth. This bureau growth was claimed to lead to the worsening of static technical and allocative inefficiencies.

The basic relationship tested in Equation (1) took several forms, depending on the expressions used for expenditures and employment. Categories of expenditures tested included 1) police, fire, and sewer as a measure of basic services, 2) police and fire without sewer, 3) total expenditures, and 4) municipal employment.

\section{EMPIRICAL RESULTS}

In Table 1, three spending categories and municipal employment are estimated for all 403 cities. Of the control variables, intergovernmental aid (IR);

TABLE 1

Effects of Annexation on Percentage Change in Municipal Spending and Employment (1960-1970)

\begin{tabular}{lcccc}
\hline \hline $\begin{array}{l}\text { Dependent } \\
\text { Variable }\end{array}$ & $\begin{array}{c}\text { Police, Fire, } \\
\text { and Sewer } \\
\text { Expenditures }\end{array}$ & $\begin{array}{c}\text { Police and } \\
\text { Fire } \\
\text { Expenditures }\end{array}$ & $\begin{array}{c}\text { Total } \\
\text { Expenditures }\end{array}$ & $\begin{array}{c}\text { City } \\
\text { Employment }\end{array}$ \\
\hline Intercept & 0.2680 & 0.3353 & 0.311 & 0.536 \\
PANX & 0.6743 & 0.328 & 0.666 & 0.202 \\
& $(4.119)^{*}$ & $(3.787)^{* * *}$ & $(3.086)^{* * *}$ & $(2.162)^{* *}$ \\
PNW & 0.014 & 0.010 & 0.011 & 0.005 \\
& $(3.864)^{* * *}$ & $(5.307)^{* * *}$ & $(2.254)^{* *}$ & $(2.595)^{* * *}$ \\
MFY & 0.364 & 0.196 & 0.101 & 0.604 \\
& $(1.641)$ & $(1.677)^{* *}$ & $(0.345)$ & $(4.794)^{* * *}$ \\
IR & 0.006 & 0.001 & 0.008 & 0.0007 \\
& $(2.600)^{* * *}$ & $(1.037)$ & $(2.585)^{* *}$ & $(0.542)$ \\
MC & -0.106 & -0.051 & -0.154 & -0.040 \\
& $(-1.489)$ & $(-1.357)$ & $(-1.648)$ & $(-0.977)$ \\
SUNB & 0.022 & -0.0460 & 0.181 & 0.060 \\
& $(0.321)$ & $(-1.249)$ & $(1.980)$ & $(1.509)$ \\
D & 0.773 & 1.086 & 0.813 & 0.920 \\
& $(4.298) * * *$ & $(11.425)^{* * *}$ & $(3.428)^{* * *}$ & $(8.975)^{* * *}$ \\
F & 17.353 & 50.975 & 9.430 & 28.849 \\
R & 0.235 & 0.476 & 0.143 & 0.338 \\
n & 403.00 & 403.00 & 403.00 & 403.00 \\
\hline
\end{tabular}

Source: Data for analysis are from Commerce Department, Bureau of the Census, Census of the Population, 1970; County and City Data Book, 1962 and 1972; Survey of Governments, Governmental Finances, 1962 and 1972, Governmental Organization, 1972. $* * *, * *, *$ - significant at the $.01, .05$, and 0.10 levels, respectively. All monetary data are in real terms, 1970 dollars.

PANX = percent change in city population due to annexation, 1960-70.

$\mathbb{R}=$ percent change in intergovernmental revenues, 1960-70.

$M C=1$ if in SMSA, otherwise MC $=0$.

PNW = percent change in nonwhite population, 1960-70.

$\mathrm{D}=$ percent change in population density of 1960 city area, 1960-70.

MFY = percent change in median family income, 1960-70.

SUNB $=0$ for Sun Belt cities, 1 otherwise. 
percent change in nonwhites (PNW); median family income (MFY); and density (D) were uniformly and positively correlated with percent change in all spending categories and employment. These results are consistent with the literature. The MC variable had a uniformly negative sign in all equations, which indicates that the percentage changes in municipal expenditures were lower in metropolitan cities than in nonmetropolitan cities. The SUNB variable had a positive coefficient in all but one equation. It had significant and positive coefficients in the total expenditures and employment equations, which indicates that SUNB cities' bureau growth was less than that of cities in other regions. The SUNB cities were represented by a zero, and all other cities were represented by a one in the table.

Annexation activity, expressed as the ratio of change in population due to annexation to the 1960 population, was significant in all expenditure equations and corroborated the statistical results in the Mehay study. That is, higher annexation rates were directly correlated with higher percentage change in municipal expenditures. However, as noted above, these results do not support Mehay's argument that higher annexation rates led to greater inefficiency. The fourth equation in Table 1, which was not in the Mehay study, indicates that municipal employment was directly related to annexation activity. This result was to be expected and was consistent with the expenditure equations (see Table 2 for means of variables used in this model and in the models that follow). Again, as discussed above, nothing can be inferred about efficiency using this model form.

TABLE 2

Mean Percent Change, 1960-1970

City employees

37.6

City employees per capita

19.4

Total municipal expenditures

48.9

Total municipal expenditures per capita

28.5

Police, fire, and sewer expenditures

49.9

Police, fire, and sewer expenditures per capita

28.9

Police and fire expenditures

46.3

Police and fire expenditures per capita

26.4

Population due to annexation

12.2

Nonwhite population

89.3

Median family income

39.5

Intergovernmental revenue

165.4

Population density of 1960 city area

5.1

*All monetary data expressed in 1970 dollars.

To answer the question of what happens to efficiency as annexation takes place, appropriate indicators of efficiency must be tied to annexation. As discussed above, a better measure of efficiency includes an accounting of how expenditures per capita and employment per capita change with annexation. By 
TABLE 3

Effects of Annexation on Percentage Change in Per Capita Municipal Spending and Employment (1960 - 1970)

\begin{tabular}{lcccc}
\hline \hline Dependent & $\begin{array}{c}\text { Police, Fire, } \\
\text { and Sewer } \\
\text { Expenditures }\end{array}$ & $\begin{array}{c}\text { Police and } \\
\text { Fire } \\
\text { Expenditures }\end{array}$ & $\begin{array}{c}\text { Total } \\
\text { Expenditures }\end{array}$ & $\begin{array}{c}\text { City } \\
\text { Employment }\end{array}$ \\
\hline Intercept & 0.2553 & 0.725 & 0.2816 & 0.0891 \\
PANX & -0.056 & -0.269 & -0.092 & -0.366 \\
& $(-0.431)$ & $(-4.043)^{*}$ & $(-0.494)$ & $(-5.033)^{* * *}$ \\
PNW & 0.006 & 0.004 & 0.004 & 0.002 \\
& $(2.043)^{* *}$ & $(2.780)^{* * *}$ & $(1.051)$ & $(1.302)$ \\
MFY & 0.226 & 0.076 & 0.046 & 0.387 \\
& $(1.280)$ & $(0.846)$ & $(0.180)$ & $(3.934)^{* * *}$ \\
IR & 0.004 & 0.0007 & 0.004 & 0.0003 \\
& $(2.235)^{* *}$ & $(0.751)$ & $(1.615)$ & $(0.283)$ \\
MC & -0.120 & -0.077 & -0.150 & -0.061 \\
& $(-2.188)^{* *}$ & $(-2.751)^{* * *}$ & $(-1.840)^{*}$ & $(-1.923)^{*}$ \\
SUNB & 0.043 & -0.015 & 0.180 & 0.067 \\
& $(0.773)$ & $(-0.539)$ & $(2.270)^{* *}$ & $(2.155)^{* *}$ \\
D & -0.277 & -0.085 & -0.235 & -0.151 \\
& $(-1.927)^{*}$ & $(-1.164)$ & $(-1.145)$ & $(-1.839)^{*}$ \\
F & 2.584 & 5.254 & 2.00 & 7.684 \\
R & 0.044 & 0.085 & 0.034 & 0.120 \\
$n$ & 403.00 & 403.00 & 403.00 & 403.00 \\
\hline
\end{tabular}

Source: Data for analysis are from Commerce Department, Bureau of the Census, Census of the Population, 1970; County and City Data Book, 1962 and 1972; Survey of Governments, Governmental Finances, 1962 and 1972, Governmental Organization, 1972.

$* * *, * *$, and * - significant at the $0.01,0.05$, and 0.10 levels, respectively.

All monetary data are in real terms, 1970 dollars.

PANX = percent change in city population due to annexation, 1960-70.

PNW = percent change in nonwhite population, 1960-1970.

MFY = percent change in median family income, 1960-1970.

IR - percent change in intergovernmental revenues, 1960-70.

$M C=1$ if in SMSA, otherwise MC $=0$.

SUNB $=0$ if Sun Belt city, 1 otherwise.

$\mathrm{D}=$ percent change in population density of 1960 city area, 1960-70.

specifying the dependent variables on a per capita basis, the results change dramatically, as shown in Table 3. When expenditures and employment were expressed on a per capita basis, the annexation variable had a negative sign in all equations. The police and fire expenditures equation and the employment equation produced significant coefficients. Another notable change is the much lower $\mathrm{R}^{2}$ in all equations. These results do not suggest that higher annexation rates led to increased bureau inefficiency. For the expenditure equations, the appropriate interpretation is probably a combination of the following: (1) spending and taxation per person went down at higher annexation rates, and (2) municipal resources were spread over more people at high annexation rates, which reduced services per capita (reduced spending per capita), or bureau inefficiency increased as suggested by Mehay, but other increases in efficiency offset the bureau inefficiency. 
Since we cannot be certain which interpretation is appropriate, a more convincing indicator of the impact of annexation on bureau inefficiency is necessary. The answer is embodied in the sign of the annexation variable in the fourth equation. The negative and significant coefficient indicates that city employment did not rise proportionately with the number of people annexed. This evidence is more conclusive than that produced in the expenditure equations in Table 3. It suggests that bureau employment per capita grew, but at rates that were inverse to the rate of population growth from annexation. For example, if population growth rate went up by one unit measured in percent terms as a result of annexation, keeping the controls constant, employment per capita growth rate went down by 0.366 units, also measured in percent terms. This situation means that bureau growth, which was positive and can be closely tied to employment levels, did not increase proportionately with increased annexation. ${ }^{7}$ This final result is consistent with the other equations in Table 3 and provides more direct evidence that Mehay's interpretation was probably wrong. From these findings, one can infer that annexation produces bureau growth (increases in employment and expenditures) at rates less than those at which the population grows from the annexation process. This result suggests that the LAFCOs in California did not increase bureau inefficiency during the time period studied as far as increased annexation was concerned. However, bureau inefficiency might be found on grounds not considered in this study.

\section{SUMMARY AND CONCLUSIONS}

Using a sample of 403 cities, this study has estimated the statistical linkage between annexation of people and changes in per capita spending and per capita city employment. Statistically significant inverse relationships were found among annexation rates of people and percent growth rates in per capita police and fire expenditures and percent growth rates in per capita city employment. These findings do not support Mehay's conclusion that rapid annexation rates promote inefficiency. Furthermore, these findings cast doubt on Mehay's conclusion that LAFCOs in California produce bureau inefficiency because of high annexation activity. Although bureau growth does occur with growth in city size, the linkage between various categories of municipal expenditures (and employment) and annexation rates provides no evidence that high annexation rates lead to inefficiency in government. Annexation does increase the service monopoly position of growing cities, but this study, with the use of a multistate sample, showed no evidence that high annexation rates led to bureau inefficiency through higher per capita ex- 
penditures or through higher per capita employment. Consequently, the inefficiency argument of annexation must be sought on other grounds.

This study did find evidence of decreased growth rates in per capita police and fire expenditures as well as per capita municipal employment as annexation rates increased. Although the results of this paper are based on data from the 1960 s, they are relevant in today's environment because the same forces that drove annexations in the 1960s still drive annexations today.

These findings were for cities with a population of at least 25,000 at the beginning of the decade. One might find different results for cities with less than 25,000 people. A weakness of the method used in this and similar studies is that many of the data pertaining to municipal expenditures and annexation activity are the result of self-reporting by cities, which results in possible data bias and reduced sample size. Consequently, the results of this study might not apply to the omitted cities.

\section{ENDNOTES}

1. The city of San Francisco is coterminous with the surrounding county and is treated as an exception.

2. Annexation, demographic, and socioeconomic data were from the Census of the Population, 1970; The County and City Data Book, 1962, 1972; The Survey of Governments, 1962, 1972; Adjusting Municipal Boundaries: Law and Practice, 1966; and Governmental Organization, 1972.

All municipal cost data were converted to 1970 dollars using the Implicit Price Deflator for Governmental Goods and Services, published annually by the U. S. Department of Commerce. Family income data were converted to 1970 dollars with the consumer price index, published by the Bureau of Labor Statistics.

3. These states included Connecticut, Delaware, Hawaii, Maine, Massachusetts, New Hampshire, Rhode Island, and Vermont. See Frank S. Sengstock, Annexation: A Solution to the Metropolitan Area Problem, The University of Michigan Law School (Ann Arbor: Michigan Legal Publication, 1960) for further discussion.

4. A number of cities in nonlegislative determination annexation law states were omitted because of other missing data.

5. For further reading on this point, see Bergstrom and Goodman (1973).

6. Martin and Wagner found a weak positive association between metropolitan cities and a higher level of expenditures by all governmental units grouped together. This association may not carry over to cities only. 
7. The coefficient of the annexation variable should be interpreted as a marginal impact of changing annexation activity. Thus, the impact should be viewed only as a marginal change in the level of efficiency attained over a small change in time.

\section{REFERENCES}

Bahl, Roy W., Jr., and Robert J. Saunders. "Determinants of Changes in State and Local Government Expenditures." National Tax Journal 18, no. 1 (1965): 51-57.

Bergstrom, Theodore C., and Robert P. Goodman. "Private Demand for Public Goods." American Economic Review 63, no.3 (1973): 280-296.

Bollens, John C. "Annexation of Fringe Areas." Public Management (April 1949): 98-102.

Bromley, David G., and Joel Smith. "The Historical Significance of Annexation As a Social Process." Land Economics 49, no. 3 (1973): 294-309.

Brown, Bernard. "Municipal Finances and Annexation: A Case Study of Post-War Houston." The Southwestern Social Sciences Quarterly 48, no. 3 (1967/68): 339-351.

Cho, Yong Hyo. "Fiscal Implications of Annexation: The Case of Metropolitan Central Cities in Texas." Land Economics 45, no. 3 (1969): 368-372.

Dusenbury, Patricia J. Suburbs in the City: Municipal Boundary Changes in Southern States. Research Triangle Park, N. C.: The Southern Growth Policies Board, 1980.

Dye, Thomas R. "Urban Political Integration: Conditions Associated with Annexation in American Cities." Midwest Journal of Political Science 8 (1964): $430-446$.

Fossett, James W. Federal Aid to Big Cities, The Politics of Dependence. Washington, D.C.: The Brooking's Institution, 1983.

Gabler, L. R. "Population Size as a Determinant of City Expenditures and Employment-Some Further Evidence." Land Economics (May 1971): 130-138.

Galloway, Thomas D., and John D. Landis. "How Cities Expand: Does State Law Make a Difference?" Growth and Change 17, no. 4 (1986): 25-45.

Gustely, Richard D. "Measuring the Regional Economic Impact of Federal Grant Programs." In Fiscal Crisis in American Cities: The Federal Response, edited by L. Kenneth Hubbell, 62-63. Cambridge, Mass.: Ballinger Publishing Company, 1979. 
Hufbaur, G. C., and B. W. Severn. "Municipal Costs and Urban Area." Journal of Urban Economy 2 (1975): 199-211.

Kaufman, Ira R., and Leo F. Schnore. Municipal Annexations and Suburbanization. Madison, Wis.: The University of Wisconsin, Center for Demography and Human Ecology, 1975.

Klaff, Vivian Z., and Glenn V. Fuguitt. "Annexation As a Factor in the Growth of U.S. Cities, 1950-1960 and 1960-1970." Demography 15, no. 1 (1978): 1-12. Liebert, Roland R. "Municipal Functions, Structure, and Expenditures: A Reanalysis of Recent Research." Social Science Quarterly (March 1974): 765-783.

Liner, Gaines H. "Annexation and Institutional Constraints." Growth and Change 21, no. 4 (Fall 1990): 80-94.

Martin, Delores T., and Richard Wagner. "The Institutional Framework for Municipal Incorporation: An Economic Analysis of Local Agency Formation Commissions in California." Journal of Law and Economics 21 (December 1975): 409-425.

MacManus, Susan A., and Robert D. Thomas. "Exploring the Tax Base: Does Annexation Make a Difference?" The Urban Interest 1, no. 2fa (1979): 15-28.

Mehay, Stephen L. "The Expenditure Effects of Municipal Annexation." Public Choice 36 (1981): 53-62.

National League of Cities. Adjusting Municipal Boundaries: Law and Practice, Washington, D.C., 1966.

Sengstock, Frank S. Annexation: A Solution to the Metropolitan Area Problem. Ann Arbor: The University of Michigan Law School, Michigan Legal Publication, 1960.

Sly, David F., and Jeffery Tayman. "Changing Metropolitan Morphology and Municipal Services Expenditures in Cities and Rings." Social Sciences Quarterly 61, nos. 3 and 4 (1980): 595-611.

U. S. Department of Commerce, Bureau of the Census. Census of the Population, Characteristics of the Population. Washington, D.C.: Government Printing Office, 1970.

. County and City Data Book. Washington, D.C.: Government Printing Office, 1962, 1972.

. Census of Governments, Governmental Finances. Washington, D.C.: Government Printing Office, 1962, 1972.

Census of Governments, Governmental Organization. Washington, D.C.: Government Pringint Office, 1972. 
Wagner, Richard E., and Warren E. Weber. "Competition, Monopoly, and Organization of Government in Metropolitan Areas." The Journal of Law and Economics 18 (1975): 661-695.

Wheeler, Raymond H. "Annexation Law and Annexation Success." Land Economics 41 (1965): 354-360. 